\title{
Collegiate Aviation and September 11, 2001: A Survey of Current Issues
}

\author{
Timm J. Bliss \\ Oklahoma State University \\ Mavis F. Green \\ Middle Tennessee State University \\ Angel R. Larsen \\ Oklahoma State University
}

\begin{abstract}
Issues of importance to the collegiate aviation community as a result of September 11, 2001 are still surfacing. With that in mind, the researchers felt it of great importance to determine what continuing effects from September 11th collegiate flight programs might be experiencing. The researchers identified and surveyed 140 two-year and four-year collegiate flight programs in the United States from July to August 2004. Results show that $84 \%$ of schools surveyed report the September 11, 2001 terrorist attacks directly affected their collegiate flight program. A majority (86\%) reported increased insurance premiums and a majority also agreed that insurance costs are a primary threat to their collegiate flight program. Due to the increase in flight insurance premiums, $70 \%$ reported increased student flight costs to offset this increase in operating expenses. Other issues addressed in the survey include general student enrollment, international student enrollment, increased security measures, student costs, and reduction in fleet size.
\end{abstract}

\section{INTRODUCTION}

There are approximately 275 postsecondary institutions offering aviation programs in such disciplines as flight training, management, and maintenance (US Department of Education, 1998). Currently, collegiate aviation is the primary source of pilots to serve the commercial aviation industry and the need for these pilots is to remain high in the foreseeable future (Green, 2003). More than $85 \%$ of all pilots hired by the major airlines have college degrees of some kind (Phillips, 2003).

However, as a result of the terrorist attacks in September 2001, the outlook for the aviation community has been uncertain. When the United States shut down the National Airspace System (NAS), the majority of commercial and general aviation aircraft were grounded, airports across the nation were closed, and passenger demand for air travel decreased. Collegiate flight training was temporarily shut down as well. This intensified the economic crisis collegiate flight training faced prior to September 11, 2001, exemplified by exponential increases in insurance costs and higher fuel costs (National Association of Flight Instructors, 2001). As a result, financial woes worsened for these flight programs when restrictions kept their planes on the ground. It took up to two months after the terrorist attacks before some flight programs fully reopened. Years later, flight programs, airlines, and others in the aviation community are still in survival mode (La Corte, 2002).

When the National Airspace System was shut down on September 11, 2001, most collegiate flight programs took the loss much like the rest of the nation's general aviation community. The temporary setback of visual flight rules (VFR) flight training operations (private pilot certification) was unwelcome during the approximately eleven days that VFR operations were prohibited across the nation. Collegiate flight schools were unable to conduct 90 to $100 \%$ of their daily flight training operations, interrupting the education of more than 10,000 college students pursuing a degree in professional pilot studies (National Association of Flight Instructors, 2001).

Average daily losses during this time period ranged from $\$ 1,000$ in revenues for the smaller schools to upwards of $\$ 10,000$ for the largest collegiate flight schools (Boatman, 2001). While these schools posted daily losses, their fixed costs (mortgage, insurance, and aircraft 
payments) continued at the rate of thousands of dollars per day. This loss in flight revenue could hardly have come at a worst time. Collegiate flight schools already faced insurance premium increases of up to $50 \%$ for the year, and few, if any, insurance companies were able, or willing, to offer relief from premium payments during this crisis (Boatman, 2001).

\section{RESEARCH METHODOLOGY}

Clearly, the aviation industry has undoubtedly experienced turbulent times and may face significant restructuring in the next few years. This research study was designed to explore the effects of current trends and issues, including the September 11 terrorist attacks, on collegiate flight programs across the nation.

The sole source of data for this research study was 140 collegiate flight programs located across the United States. The participating flight programs were 4-year public and private universities and 2-year public and private colleges offering comprehensive aviation curricula. Only those collegiate flight programs awarding college degrees in aviation disciplines (Associate or Bachelor's) were selected by the researchers to participate in the study.

The quantitative measure used in this study consisted of a research questionnaire administered electronically to each of the 140 collegiate flight schools. The 54-question research instrument was developed to collect demographic and financial data regarding the individual collegiate flight programs and to assess the responses of the participants (deans, flight center managers, chief flight instructors, etc.) regarding student enrollment, financial and security concerns as a result of recent issues and trends affecting the aviation community. Respondents were also asked to give nominal and ordinal responses to a series of statements using scales related to their collegiate flight program. The research instrument also offered respondents an opportunity to provide any additional comments they felt would be appropriate to this study. All responses and comments were kept anonymous.

In disseminating the research instrument, the researchers were interested in learning the views of these collegiate flight schools regarding four specific topics:

(1) What are the characteristic profiles of the collegiate flight programs representing both the two-year and the four-year institutions across the nation?

(2) What are the financial accountabilities of the collegiate flight programs?

(3) What are the security concerns and/or issues facing the collegiate flight programs across the nation?

(4) What were the overall effects of the September 2001 terrorist attacks on the collegiate flight programs?

\section{RESULTS}

The research instrument, Collegiate Aviation and September 11, 2001: A Survey of Current Issues, was electronically mailed to 140 collegiate flight programs located in the United States. Eighty completed instruments were received from the 140 flight schools that were initially mailed a research instrument. The 80 research instruments returned by the collegiate flight programs yielded an overall response rate of 57 percent.

Table 1 presents data that characterizes the educational institutional affiliation of the 80 collegiate flight programs responding to the instrument.

The type of academic degrees that flight students can earn in the responding collegiate flight programs are presented in Table 2. As shown in the table, forty-two percent of the flight schools offer an Associate's degree. Furthermore, thirty-eight percent of all responding flight schools offer a Bachelor of Science degree. Lastly, twenty percent of the flight programs offer both academic degrees.

Table 1. Educational Affiliation of Each Responding Collegiate Flight Program

\begin{tabular}{lcc}
\hline Educational Institution & Number of Respondents & Percent of Respondents \\
\hline 4-year institution & 46 & $57 \%$ \\
2-year institution & 34 & $43 \%$ \\
\hline
\end{tabular}


Table 2. Academic Degrees Offered by Each Responding Collegiate Flight Program

\begin{tabular}{lcc}
\hline Academic Degree & $\begin{array}{c}\text { Number of } \\
\text { Respondents }\end{array}$ & $\begin{array}{c}\text { Percent of } \\
\text { Respondents }\end{array}$ \\
\hline Associate & 33 & $42 \%$ \\
Bachelor of Science & 30 & $38 \%$ \\
Both & 16 & $20 \%$ \\
\hline
\end{tabular}

Sixty-eight percent of the collegiate flight programs responding to the survey have provided flight training for more than 15 years. Thirty-four of the 80 responding flight schools have actually been in operation for more than 30 years. The response rate of the 80 flight schools that stated how many years they have been in operation are presented below in Table 3 .

Table 3. Total Number of Years Respondents Have Been in Operation

\begin{tabular}{lcc}
\hline $\begin{array}{c}\text { Number of Years Collegiate Flight Programs } \\
\text { Have Been in Operation }\end{array}$ & $\begin{array}{c}\text { Program } \\
\text { Response }\end{array}$ & $\begin{array}{c}\text { Percent of } \\
\text { Response }\end{array}$ \\
\hline $0-15$ Years & 26 & $32 \%$ \\
$16-30$ Years & 20 & $25 \%$ \\
$31-45$ Years & 20 & $25 \%$ \\
Over 45 Years & 14 & $18 \%$ \\
\hline
\end{tabular}

Each collegiate flight program was asked how many full-time students are currently enrolled in their flight program. Table 4 identifies the flight Table 4. Full-time Flight Students Enrolled in Each Responding Collegiate Flight Program

\begin{tabular}{lcc}
\hline $\begin{array}{l}\text { Number of Full-time Students Enrolled } \\
\text { in Each Collegiate Flight Program }\end{array}$ & $\begin{array}{c}\text { Program } \\
\text { Response }\end{array}$ & $\begin{array}{c}\text { Percent of } \\
\text { Response }\end{array}$ \\
\hline 1 - 100 Full-time Students & 46 & $57 \%$ \\
$101-250$ Full-time Students & 27 & $34 \%$ \\
251 - 500 Full-time Students & 4 & $5 \%$ \\
Over 500 Full-time Students & 3 & $4 \%$ \\
\hline
\end{tabular}

As shown in Table 4, fifty-seven percent of the collegiate flight schools responding to this study indicated they have at least 100 full-time flight students enrolled in their program. About one-third of the respondents stated they have 101 to 250 full-time students. Nine percent of the flight programs have full-time enrollment of over 250 students. Two follow-up questions on the research instrument asked the flight schools how many full-time female and international students school's responses regarding enrollment of fulltime flight students.

are currently enrolled in their flight programs. The majority of responding collegiate flight programs, 93 percent, stated that 20 percent or less of fulltime students are female; and 92 percent of the flight programs indicated that only 20 percent or less of their full-time students are from foreign countries.

The collegiate flight programs were asked to approximate the typical flight costs for a student earning a private pilot certificate in their flight 
program. This information is presented in Table 5. The flight costs were sub-grouped into four separate categories: $\$ 0$ - $\$ 5,000 ; \$ 5,001$ - $\$ 7,500$; $\$ 7,501$ - $\$ 10,000$; and more than $\$ 10,000$. Approximately 85 percent of the 80 flight programs reported the flight costs for a student earning a private pilot certificate from their flight school is less than $\$ 7,500$. Five collegiate programs, or 6 percent, indicated the flight costs for a private pilot certificate is more than $\$ 10,000$ at their school.

Table 5. The Flight Costs for a Student Earning a Private Pilot Certificate

\begin{tabular}{lcc}
\hline $\begin{array}{c}\text { Student Flight Costs for Earning } \\
\text { Private Pilot Certificate }\end{array}$ & $\begin{array}{c}\text { Number of } \\
\text { Respondents }\end{array}$ & $\begin{array}{c}\text { Percent of } \\
\text { Respondents }\end{array}$ \\
\hline$\$ 0-\$ 5,000$ & 37 & $47 \%$ \\
$\$ 5,001-\$ 7,500$ & 30 & $38 \%$ \\
$\$ 7,501-\$ 10,000$ & 7 & $9 \%$ \\
Over $\$ 10,000$ & 5 & $6 \%$ \\
\hline
\end{tabular}

A statement in the research instrument asked the respondents what percent of their flight students receive some form of campus-based financial assistance. Approximately three-fourths, 74 percent, stated that at least 50 percent of their students received financial assistance to assist them with their flight costs. Furthermore, 68 percent of flight programs offer aviation internships and/or scholarship opportunities to assist their student pilots with flight training costs.

Table 6 indicates the average age (manufacture date) of each responding collegiate flight program's aircraft fleet. Almost half (47 percent) of the respondents have aircraft that are between 11 and 20 years old, and 9 percent of collegiate flight programs responding to the survey have fleets that are over 20 years old

Table 6. Average Age of Respondents' Aircraft Fleet

\begin{tabular}{lcc}
\hline $\begin{array}{c}\text { Average Age (Manufacture Date) } \\
\text { of Aircraft Fleet }\end{array}$ & $\begin{array}{c}\text { Number of } \\
\text { Respondents }\end{array}$ & $\begin{array}{c}\text { Percent of } \\
\text { Respondents }\end{array}$ \\
\hline $1-5$ Years & 10 & $14 \%$ \\
$6-10$ Years & 22 & $30 \%$ \\
$11-15$ Years & 26 & $36 \%$ \\
$16-20$ Years & 8 & $11 \%$ \\
Over 20 Years & 7 & $9 \%$ \\
\hline
\end{tabular}

A follow-up question asked each flight program how they typically acquire their aircraft fleet. Seventy-three percent of the flight schools indicated they purchase new aircraft. One of the 4year flight schools responding to the survey commented, "We purchase a mix of new and used aircraft since some of the aircraft we use such as the Cessna 310 are not available as new aircraft." When asked where the schools acquire the capital for purchasing aircraft, 40 percent of the flight programs receive allocations from their college or university and 35 percent use revenues from their flight program to purchase new aircraft. A responding 2-year school stated, "We acquired our fleet of aircraft after leasing them for a year and then purchasing them on a grant. We do not have means to replace aircraft other than from grants." Lastly, approximately two-thirds (66 percent) of the flight programs reported that the city or county owned the airport where the school operates their 
collegiate flight training. Only 12 percent of the flight schools responding to the study stated that their college or university owns the airport.

The Likert-type research instrument statements regarding the perceptions of the collegiate flight program respondents are presented in Table 7. The respondents indicated their perceptions with these statements on fourpoint Likert scales.

Table 7. Responses of Collegiate Flight Programs Regarding the Effects of the September 11, 2001 Terrorist Attacks on Collegiate Aviation

Number of Responding Flight Programs - Percent of Total Respondents

\begin{tabular}{|c|c|c|c|c|}
\hline Likert-Type Statements & SA & A & $\mathbf{D}$ & SD \\
\hline $\begin{array}{l}\text { The effects of the September } 11,2001 \text { terrorist attacks have created a } \\
\text { negative public perception of collegiate flight training programs in the } \\
\text { U.S. }\end{array}$ & $\begin{array}{l}2 \\
2 \%\end{array}$ & $\begin{array}{l}24 \\
30 \%\end{array}$ & $\begin{array}{l}38 \\
48 \%\end{array}$ & $\begin{array}{l}16 \\
20 \%\end{array}$ \\
\hline $\begin{array}{l}\text { The proposed new security measures at general aviation airports } \\
\text { (flight centers) will bring more costly changes to our collegiate flight } \\
\text { program. }\end{array}$ & $\begin{array}{l}13 \\
16 \%\end{array}$ & $\begin{array}{l}45 \\
57 \%\end{array}$ & $\begin{array}{l}18 \\
23 \%\end{array}$ & $\begin{array}{l}3 \\
4 \%\end{array}$ \\
\hline $\begin{array}{l}\text { Our institution needs to do more to improve security at our collegiate } \\
\text { flight center. }\end{array}$ & $\begin{array}{l}4 \\
5 \%\end{array}$ & $\begin{array}{l}22 \\
28 \%\end{array}$ & $\begin{array}{l}47 \\
59 \%\end{array}$ & $\begin{array}{l}6 \\
8 \%\end{array}$ \\
\hline $\begin{array}{l}\text { There will be a decline in international students in our collegiate flight } \\
\text { program due to increased scrutiny placed on these students studying at } \\
\text { U.S. colleges and universities. }\end{array}$ & $\begin{array}{l}14 \\
19 \%\end{array}$ & $\begin{array}{l}38 \\
51 \%\end{array}$ & $\begin{array}{l}21 \\
28 \%\end{array}$ & $\begin{array}{l}2 \\
2 \%\end{array}$ \\
\hline Insurance costs are a primary threat to our collegiate flight program. & $\begin{array}{l}19 \\
25 \%\end{array}$ & $\begin{array}{l}31 \\
40 \%\end{array}$ & $\begin{array}{l}24 \\
31 \%\end{array}$ & $\begin{array}{l}3 \\
4 \%\end{array}$ \\
\hline Fuel costs are a primary threat to our collegiate flight program. & $\begin{array}{l}20 \\
26 \%\end{array}$ & $\begin{array}{l}40 \\
53 \%\end{array}$ & $\begin{array}{l}15 \\
20 \%\end{array}$ & $\begin{array}{l}1 \\
1 \%\end{array}$ \\
\hline $\begin{array}{l}\text { The current cost of flight training at our collegiate flight school has an } \\
\text { effect on the ability of the typical college student to pursue an aviation } \\
\text { career (pilot) at our institution. }\end{array}$ & $\begin{array}{l}35 \\
44 \%\end{array}$ & $\begin{array}{l}31 \\
40 \%\end{array}$ & $\begin{array}{l}12 \\
15 \%\end{array}$ & $\begin{array}{l}1 \\
1 \%\end{array}$ \\
\hline $\begin{array}{l}\text { The lack of financial assistance available to flight students is a } \\
\text { primary threat to our collegiate flight program. }\end{array}$ & $\begin{array}{l}27 \\
34 \%\end{array}$ & $\begin{array}{l}22 \\
28 \%\end{array}$ & $\begin{array}{l}27 \\
34 \%\end{array}$ & $\begin{array}{l}3 \\
4 \%\end{array}$ \\
\hline $\begin{array}{l}\text { Our institution/aviation department makes efforts to develop the } \\
\text { interest of individuals from underrepresented groups (minorities and } \\
\text { women) in undertaking a career in aviation. }\end{array}$ & $\begin{array}{l}20 \\
26 \%\end{array}$ & $\begin{array}{l}54 \\
69 \%\end{array}$ & $\begin{array}{l}4 \\
5 \%\end{array}$ & $\begin{array}{l}0 \\
0 \%\end{array}$ \\
\hline
\end{tabular}

Note: The abbreviations used in the table are as follows: SA - Strongly Agree; A - Agree; D -

Disagree, and SD - Strongly Disagree.

Of those flight program respondents indicating a preference to the statement, "the effects of the September 11, 2001 terrorist attacks have created a negative public perception of collegiate flight training programs in the U.S.," 32 percent of the flight schools agreed, compared to 68 percent who disagreed with the statement. Regarding this statement, one of the flight schools added, "Only the media creates negative public perception."

\section{Security Measures}

Seventy-three percent of the collegiate flight programs agreed with the statement that "the proposed new security measures at general 
aviation airports (flight centers) will bring more costly changes to our collegiate flight program."

Seventy percent of the responding flight schools agreed with the statement "there will be a decline in international students in our collegiate flight program due to increased scrutiny placed on these students studying at U.S. colleges and universities." In support of this statement, one respondent said that screening of flight students is critical in the prevention of the misuse of aircraft and terrorist incidents. Fearing that flight schools have the potential to become training grounds for terrorists in the future, several states are seeking to restrict flight instruction and require background checks for international students. Going one step farther, some state lawmakers have even suggested that students should be barred from taking flight classes if they have been convicted of serious crimes (Hinnant, 2002).

\section{Insurance and Fuel Costs}

Two-thirds, 65 percent, of the flight schools agreed that, "insurance costs are a primary threat to our collegiate flight program" and approximately 80 percent agreed with the statement, "Fuel costs are a primary threat to our collegiate flight program." A 4-year flight school commented, "Fuel costs have not changed that much, insurance costs are out of control. They dictate how you can operate your flight program. We live close to a nuclear facility and that has had an impact also." Agreeing with the respondents, Stephen Gurr concurs that the economy has had the biggest impact on flight school in the two years since September 2001. And spiraling insurance costs and high fuel prices are big reasons why many flight schools have gone out of business in the past three years. Gurr reports that the owner and CFI of an air service company witnessed his insurance costs on a Cessna 172 jump from $\$ 2,500$ a year to $\$ 6,000$ a year in just three years.

Collegiate flight programs are in fact feeling the pain of these rising costs. The head flight instructor of a large collegiate flight program believes some of the rising operating costs, particularly insurance, stem from the threat of terrorism. Insurers believe there is a higher risk that something is going to happen to an aircraft, so naturally they want to levy that risk on the owner (Gurr, 2003). However, one of the responding 4- year schools to this study added, "Our insurance cost has increased only ten percent. Increases were more due to new aircraft than due to impacts of 9/11."

\section{Financial Assistance}

Lastly, only 16 percent of the responding collegiate flight programs disagreed with the statement that, "the current cost of flight training at our collegiate flight school has an effect on the ability of the typical college student to pursue an aviation career (pilot) at our institution." In comparison, an overwhelming 84 percent of flight schools agreed that current flight costs has an effect on the ability for students to pursue a flight program at their institution. One of the responding 4-year schools stated, "Most financial aid at our institution is utilized to pay tuition costs first, about $\$ 18,000$ year; thereafter, flight costs are subsidized by student loans." Another 4-year flight school added, "The absurdly low limits on federally-subsidized loans are a major barrier for our students. These loans do not even cover 50 percent of in-state tuition and room/board, no less flight training costs."

\section{DISCUSSIONS AND CONCLUSIONS}

The economic viability of the general aviation community was traumatized during the week of September 11, 2001. The terrorist attacks left aviation schools with many negative perceptions and financial burdens. During the shutdown, the income of the nation's approximately 2,400 general aviation flight schools, including collegiate flight schools, was effectively zero (National Association of Flight Instructors, 2001). And yet, collegiate flight programs had to continue to meet their financial obligations such as rent, electricity, and insurance for both the facilities and the planes (Poynor, 2001).

While many other businesses throughout the nation resumed productive commerce only a few weeks after the terrorist attacks, the general aviation community has not yet recovered. A flight training program on Long Island has lost about 35 percent of its business. Several students have quit and inquiries from potential students have dropped to zero (Lombardo, 2001). Moreover, many flight schools have gone out of 
business since September 2001 though the actual number is somewhat elusive (Lombardo, 2001). However; a Washington DC lobby group for general aviation and flight schools estimates that 25 percent of the nation's flight schools have gone out of business since the September 11 terrorist attacks (Gurr, 2003). Six collegiate flight programs asked to participate in this study responded they no longer offer flight training at their institutions. One of the 2-year schools remarked, "Our college no longer has an aviation program. It was cancelled due to low enrollment and budgetary constraints." A second 2-year school added, "We have since closed our flight program. We are now struggling to keep our Aviation Management program alive."

During his 2001 testimony, Phillip Poyner stated once closed, most flight schools will not reopen. The financial returns are so small that once capital has left the flight training schools it is unlikely to return. Given this dismal scenario, at some point in the future the dissolution of more flight programs across the nation may occur. As a result, we will be training fewer pilots and without pilots in the pipeline, the commercial airlines and other civil aviation employers will run short of pilots in a relatively narrow amount of time. Poynor supports this statement by indicating that approximately 30 percent of all commercial airline pilots will retire by 2007 .

Poynor's remarks and comments from several of the responding flight schools are significant because approximately 85 percent of all pilots hired by the airlines have college degrees. Plus, most corporate pilots flying for Fortune 500 companies hold college degrees. Therefore, college-educated pilots tend to have better flying jobs than those without higher education (Phillips, 2003). Furthermore, the National Academy of Sciences believes that collegiate aviation is the major source of training student pilots because it has the potential to produce pilots specifically trained to the standards recognized by the commercial air carriers (US Department of Education, 1998).

This study asked collegiate flight programs if the September 11, 2001 terrorist attacks directly affected their flight programs. An overwhelming 84 percent of respondents stated their flight programs were directly affected by the attacks. Furthermore, 75 percent of the flight schools indicated their insurance costs have increased as a result of the terrorist attacks. As a result of increased insurance costs, 70 percent of the responding flight programs stated they increased student flight costs to offset this increase in operating expenses. Lastly, only 60 percent of the collegiate flight schools reported their flight programs have returned to normal operations since the September 2001 terrorist attacks.

Though many of our collegiate flight programs are still struggling, some in the industry say things are beginning to improve. In Utah, a flight school and charter operator was shut down for three days after the 2001 attacks. His charter operation lost approximately $\$ 6,000$ a day and the flight instruction program lost about $\$ 2,500$ a day. The owner said his student enrollment remains fairly constant only because his company provides flight training for one of Utah's community colleges (Lombardo, 2001). A responding 4-year school stated, "Training in the Baltimore/DC area (where our $2+2$ program with a community college operates) was shut down completely for over four months after 9/11. Since then, it has resumed normal operations."

As time has progressed and healing has occurred, there are many collegiate flight programs coming back to levels that are reasonably close to where they were before September 2001. One of the 4-year schools responding to this study stated, "We will be back (slightly beyond) to 2001 levels with the number of currently paid applicants for the fall 2004 entering class. We will be up 6 students from 2001." Another 4-year school added, "We are normal in our operations, but our enrollment has not returned to the levels we had for the fall 2001 enrollment." And yet, there is that final comment from one of the responding 2-year flight schools, "Here is a news flash. No one will ever be back to normal after 9/11." 


\section{REFERENCES}

Boatman, J.K. (2001, December). Uncertain times: Flight training continues under scrutiny. AOPA Flight Training, 12-15.

Green, M.F. (2003, Spring). Collegiate flight program trends post 9/11. Collegiate Aviation News 27, (2) p.7.

Gurr, S. (2003, July 6). Unfriendly skies; Flight schools feel strong sting of economy, high costs. Augusta Chronicle. Retrieved September 14, 2004, from: http:/www.augustachronicle.com/stories/ 070603/bus_072-7697.000.shtml

Hinnant, L. (2002, March 15). States are offering proposals to regulate flight schools; FAA wants them to butt out. San Francisco Chronicle. Retrieved October 28, 2004, from: http://www.sfgate.com/cgibin/article.cgi?file=/news/archive/2002/03/15

LaCorte, R. (2002, August 24). Flight schools recovering slowly from stigma of training terrorists. Naples Daily News. Retrieved February 17, 2004, from: http://www.naplesnews.com/ 02/08/florida/d814809a.htm

Lombardo, D.A. (2001, November). Terrorism takes toll on the flow of new pilots. Aviation International News. Retrieved October 1, 2004, from: http://www.ainonline.com/issues/11_01/ 11_01_terrorismpg10.html

National Association of Flight Instructors (2001). Executive summary. Retrieved September 21, 2004, from: http://www.nafinet.org/news/2001\%20-\%2009_25\%20\%-20Executive\%20Summary.html

Phillips, W. (2003, December). Small, medium, extra large: Higher education that fits. AOPA Flight Training, 21-25.

Poberezny, T. (2001, September 25). Selected issues relating to the general aviation industry after the September 11, 2001 terrorist attacks. Hearing before the Subcommittee on Aviation of the Committee on Transportation and Infrastructure, House of Representatives. Retrieved October 27, 2004, from: http://www.house.gov/transportation/aviation/09-21-01/poberezny.html

Poynor, P. (2001). Testimony of Phillip Poynor. Retrieved October 22, 2004, from: http://www.nafinet.org/news/2001\%20-\%2009_25\%20\%20-

\%20Testimony\%20of\%20Phillip\%20Poynor.html\#TopOfPage

United States Department of Education. (1998, September). Taking flight: Education and training for aviation careers. Retrieved February 1, 2005, from: http://www.ed.gov/offices/OUS/PES/ higher/civilai2.html 